\title{
Distribution of alkaline phosphatase in serum protein fractions
}

\author{
N. H. KORNER \\ From the Department of Medicine, St. Vincent's Hospital, Sydney, Australia
}

SYNOPSIS A technique for measuring the alkaline phosphatase activity of serum protein fractions separated by electrophoresis on cellulose acetate strips is described.

Alkaline phosphatase activity in alpha 2, alpha 1, and beta globulins and in albumin is present in varying proportions in normal and pathological sera. In normal sera peak activity is in the alpha 2 globulins and beta globulins have a little more than half the alpha 2 activity. Albumin activity is often more than $10 \%$ of the total, but alpha 1 and gamma globulin activity is less than this.

In bone disorders with a high serum alkaline phosphatase a large, and sometimes predominant, part of the increase is due to raised beta globulin phosphatase activity, and alpha 2 activity is also raised. Alpha 1 activity, though usually low, may be increased.

In hepatobiliary disorders with a high phosphatase concentration the increase is due mainly to raised alpha 2 phosphatase activity, and there is also an increase in alpha 1 phosphatase. Beta activity is usually, but not always, low, and albumin activity may be somewhat increased in obstructive jaundice and liver metastases. There is some overlap between these two patterns of alkaline phosphatase distribution. The findings are consistent with the possibility that alkaline phosphatases in different protein fractions are derived from different tissues.

Alkaline phosphatase activity has been reported in three fractions of electrophoretically separated serum proteins, the alpha 2 , alpha 1 , and beta globulins. Paper (Baker and Pellegrino, 1954) and starch (Rosenberg, 1959; Keiding, 1959; Kowlessar, Pert, Haeffner, and Sleisenger, 1959) media have been used for the separation, and in normal serum peak enzyme activity is in the alpha 2 fraction. The proportion of phosphatase activity in each fraction has been found to vary in different diseases of bone and liver, and this has suggested the possibility that enzyme moving with a certain fraction may be derived from a particular tissue, or at least has some connexion with it. This relationship has been postulated for beta globulin phosphatase and bone (Keiding, 1959; Kowlessar et al., 1959) and for alpha 1 globulin phosphatase and liver (Rosenberg, 1959; Keiding, 1959) on the basis of increased enzyme activity found in those fractions in some cases of bone and liver disease respectively. Increased alpha 2 globulin phosphatase activity has been found in both liver and bone disease. Thus the heterogeneous constitution of plasma alkaline phosphatase is well established, but it remains uncertain whether liver

Received for publication 2 October 1961. (and possibly other tissues) as well as bone acts as a source of the enzyme in the blood.

The present work was carried out in association with a study of the sera of two patients with hypophosphatasia and their relatives (Korner, 1962). A relatively simple method of measuring the alkaline phosphatase activity of the serum protein fractions was developed, and the results of observations on 76 sera from normal subjects and patients with liver and bone diseases are presented here.

\section{METHOD}

Serum electrophoresis was carried our on cellulose acetate (Oxoid) strips $(5 \times 20 \mathrm{~cm}$.). Serum, $0.01 \mathrm{ml}$., was applied from a thin capillary along a line $7.7 \mathrm{~cm}$. from the end of the strip. A barbital buffer was used $(p \mathrm{H} \mathrm{8.6,}$ $0.06 \mathrm{M}$ ), and with a current of $0.3 \mathrm{~mA}$ per $\mathrm{cm}$. width of strip, the duration of the run was four hours. The apparatus was kept at a temperature of about $4^{\circ} \mathrm{C}$.

A third of each strip was cut off longitudinally after the run and stained for protein. While the stained strip was still moist (to prevent errors arising from shrinkage on drying) it was juxtaposed to the unstained portion, and the position of each protein band was drawn on the latter in pencil. The parts of the strip containing the protein fractions and the intervening segments were cut 
out and placed in separate test tubes. A segment of the strip was also cut as a blank.

The estimation of alkaline phosphatase activity was based on the method of Bessey, Lowry, and Brock (1946). To each tube was added (in an ice bath) $0.2 \mathrm{ml}$. of water and $0.8 \mathrm{ml}$. of buffered disodium p-nitro phenyl phosphate substrate.

Solutions containing $0.01,0.02,0.08$, and $0.10 \mathrm{mM} / 1$. of p-nitro phenol served as standards, and $0.2 \mathrm{ml}$. of each of these and a water blank were treated in exactly the same way as the test preparations. The tubes were now transferred to a water incubator at $37^{\circ} \mathrm{C}$. and incubated for one hour exactly. The enzyme reaction was stopped by returning the tubes to the ice bath and adding $1.6 \mathrm{ml}$. of $0.2 \mathrm{~N} \mathrm{Na} \mathrm{OH}$ to each.

Optical densities of blanks, standards, and tests were read at $415 \mu$ in a Unicam spectrophotometer before and after adding three drops of $5 \mathrm{~N} \mathrm{HCl}$. Enzyme activity could be read from a graph constructed from the corrected optical densities (i.e., optical density in alkaline solution less the optical density in acid solution) of the blank and standards. The percentage of total activity in each protein and intermediate zone was calculated, and from the total serum alkaline phosphatase concentration the activity in each fraction was derived.

Estimations on each serum were done in duplicate.

\section{RESULTS}

NORMALS Sera from 12 normal adults and seven children (patients with no evidence of abnormality of alkaline phosphatase metabolism) were studied
(Figs. 1, 2, and 3, A and B). The peak of alkaline phosphatase activity was in the alpha 2 globulins. Beta globulins had, on an average, somewhat more than half the activity of the alpha 2 globulins. (One adult and one child had peak beta activity on one estimation, but this was reversed when the estimation was repeated.) In 10 adults and two children the albumin fraction showed more than $10 \%$ of the total activity. The alpha 1 and gamma globulins had $\vec{\circ}$ $10 \%$ or less of the total activity in all the subjects. The increased total serum alkaline phosphatase activity in children was reflected in proportionate rises in alpha 2 and beta activity, so that the distribution of the enzyme was not significantly altered. PAGET'S DISEASE In four of the six cases studied a large part of the total increase in serum alkaline 0 phosphatase was due to increased beta globulin activity, and in two of these cases beta activity was $>$ greater than alpha 2 (Figs. 1, 2, and 3, C). In the remaining two cases increased alpha 2 activity $\vec{\oplus}$ accounted for most of the rise in total alkaline phosphatase, and in one of them alpha 1 activity was high. One additional case of Paget's disease and portal cirrhosis showed a rise in beta and alpha 2 activity, with low alpha 1 activity.

BONE METASTASES In two cases of bone metastases from carcinoma of the prostate with raised total 

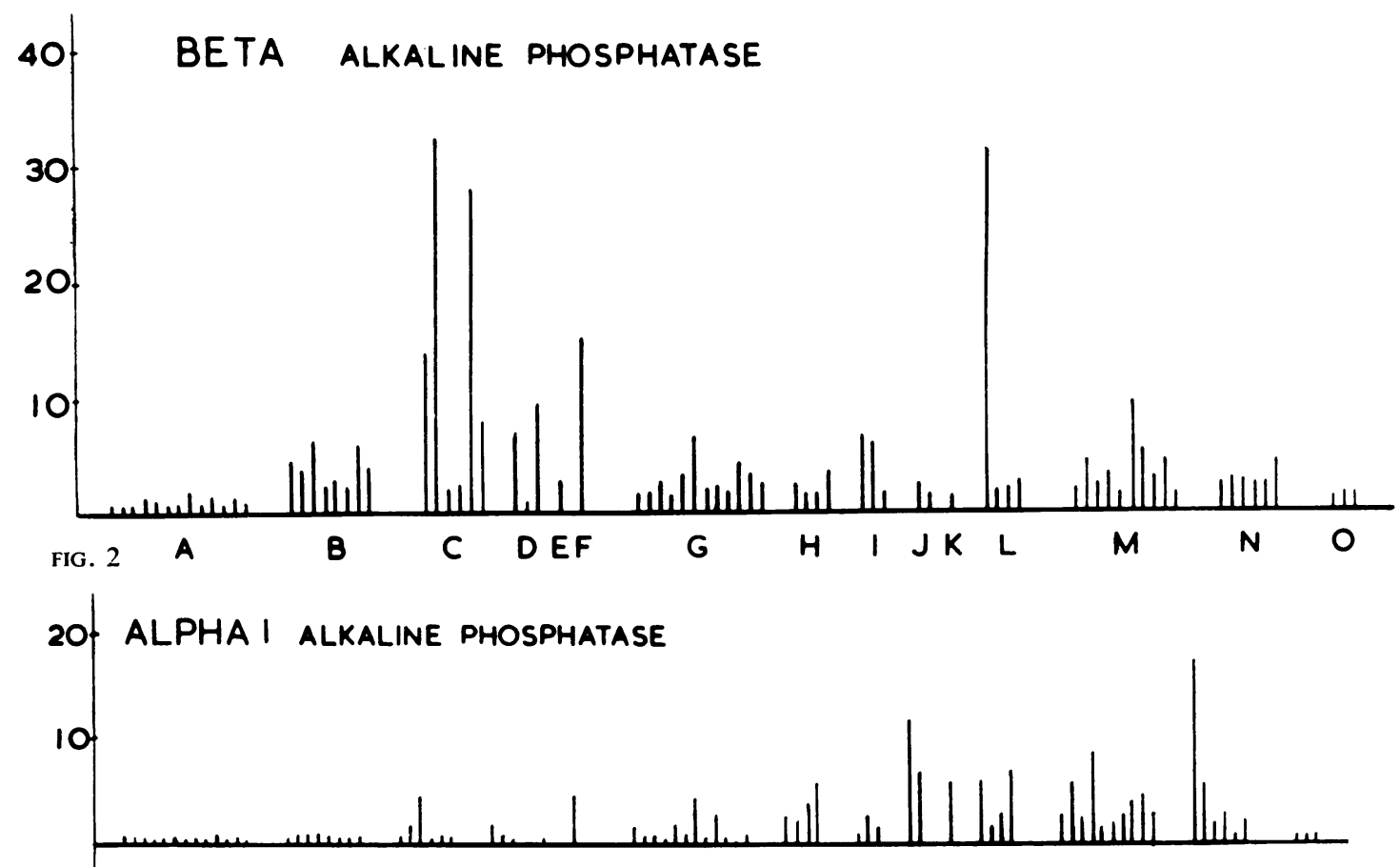

ALBUMIN alkaline phosphatase

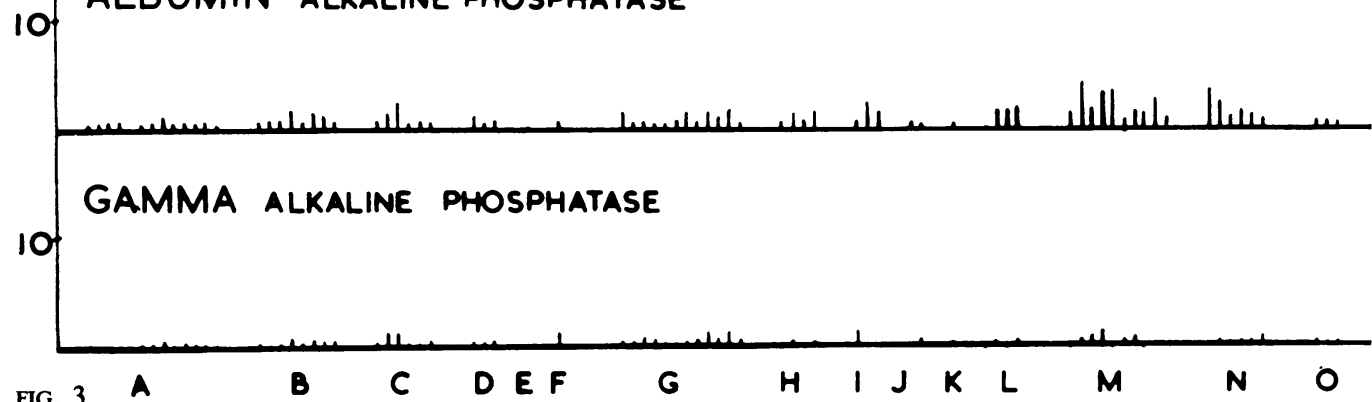

FIG. 3

FIGS. 1, 2, and 3. Concentration of alkaline phosphatase in King-Armstrong units per $100 \mathrm{ml}$. serum.
$A$, normal adults
$B$, normal children
$C$, Paget's disease
$D$, bone metastases, carcinoma of prostate
E, osteoporosis
$F$, osteomalacia
$G$, infectious hepatitis
$H$, other forms of hepatitis

serum alkaline phosphatase, the rise was due to increased beta and alpha 2 activity (Figs. 1, 2, and $3, \mathrm{D})$. One of these cases had predominant beta activity. Another case without a rise in the total alkaline phosphatase level had a normal enzyme distribution.
I, portal cirrhosis

$J$, biliary cirrhosis

$K$, haemochromatosis

$L$, ulcerative colitis

$M$, obstructive jaundice

$N$, hepatic metastases

$O$, lactating mothers

A patient with obstructive jaundice due to gall stones, carcinoma of the prostate, and bone metastases had markedly increased beta as well as alpha 2 enzyme activity.

A patient with carcinoma of the breast and metastases in liver and bone had a low beta level, 
but increased enzyme activity in alpha 1 as well as alpha 2.

OSTEOMALACIA In one case studied the rise in serum alkaline phosphatase was due to increased beta and alpha 2 activity; alpha 1 activity was also high (Figs. $1,2$, and $3, \mathbf{F})$.

OSTEOPOROSIS In one case, total enzyme levels and distribution were normal (Figs. 1, 2, and 3, E).

INFECTIOUS AND OTHER FORMS OF HEPATITIS In the 12 cases of infectious hepatitis studied all but four had total serum alkaline phosphatase levels above normal. The rise was mostly due to increased alpha 2 activity, though there was some associated increase in beta and alpha 1 levels (Figs. 1, 2, and 3, G and H).

In a case of continuing hepatitis with a high total alkaline phosphatase the rise was also mainly due to increased alpha 2 activity and this was also true of one case each of infectious mononucleosis hepatitis, hepatitis associated with polyarteritis, and paraamino salicylic acid hepatitis, in all three of which high total serum enzyme levels were present. The alpha 1 activity was increased.

CIRRHOSIS Of three cases of portal cirrhosis with increased total serum alkaline phosphatase, the increase in two was due to raised beta as well as alpha 2 activity. In the third it was mainly increased alpha 2 activity and in all alpha 1 activity was not very high.

In two cases of biliary cirrhosis alpha 2 and also alpha 1 activity was raised, but beta activity was low. This also applied to a case of haemochromatosis.

The levels in all forms of cirrhosis studied are shown in Figs. 1, 2, and 3, I, J, and $\mathrm{K}$.

ULCERATIVE COLITIS In three out of four cases with a high total serum alkaline phosphatase the predominant rise was in alpha 2 activity. In the fourth there was also a very high beta activity, and in two the alpha 1 levels were high. The levels are shown in Figs. 1, 2, and 3, L.

OBSTRUCTIVE JAUNDICE Raised enzyme activity in the 10 cases studied was due to increased alpha 2 activity, with some associated increase in beta and alpha 1 levels, both of which were quite high in some cases (Figs. 1, 2, and 3, M).

HEPATIC METASTASES Five cases (in one bone metastases were also present) showed a rise predominantly due to increased alpha 2 activity. Beta activity was low, and in one case alpha 1 activity was extremely high. The levels are shown in Figs. 1, 음 2 , and $3, \mathrm{~N}$.

LACTATING MOTHERS Sera from three lactating mothers were studied because the lactating breast is rich in alkaline phosphatase. Total serum phosphatase levels, however, remained normal, as did the pattern of enzyme distribution in the serum proteins (Figs. 1, 2, and 3, 0).

The study of two patients with hypophosphatasia and their relatives is reported in detail elsewhere (Korner, 1962). The pattern of alkaline phosphatase distribution in the serum proteins was normal.

\section{DISCUSSION}

The views of previous workers (Rosenberg, 1959; Keiding, 1959) regarding the existence in the serum of several alkaline phosphatase fractions with different electrophoretic mobilities were supported by the present study. The peak of alkaline phosphatase activity was normally found in the alpha 2 globulins, and the beta fraction had somewhat more than half the alpha 2 activity. The alpha 1 and gamma globulins had less than $10 \%$ of the total activity in normal sera. It is interesting to note that in 10 out of 12 normal adult sera, and in two out of seven normal children's sera, the albumin fraction showed more than $10 \%$ of total alkaline phosphatase activity, and the level was more than double that found in the gamma globulins. In pathological states with a high total alkaline phosphatase the proportion of activity in the albumin fraction was low, though there was some increase in albumin phosphatase activity in obstructive jaundice and liver metastases. However, most of the total rise in alkaline phosphatase levels was due to increased alpha 2 , beta, or alpha 1 activity. Two fairly distinct, though sometimes overlapping, patterns of alkaline phosphatase distribution could be distinguished.

In bone disorders with a high total phosphatase a large, and sometimes predominant part of the rise was due to increased beta globulin phosphatase activity. Thus in two out of six cases of Paget's disease, and in one out of three cases of bone metastases due to prostatic carcinoma, peak phosphatase activity was in the beta globulins. A case of osteomalacia also showed high beta activity. Increased alpha 2 phosphatase accounted for most of the remaining rise, but in one case of Paget's disease alpha 1 phosphatase was $16 \%$ of the total (4.5 K.-A. units in alpha $1 / 100 \mathrm{ml}$.) and in the patient with osteomalacia the total alpha 1 level was also high.

Hepatobiliary disorders in general differed from the above in that increased total alkaline phosphatase 
activity was mostly due to higher alpha 2 activity, and alpha 1 activity was also increased. Beta phosphatase was usually low, but sometimes it was raised, for instance, in two out of three cases of portal cirrhosis, in some cases of obstructive jaundice, and more strikingly in one out of four cases of ulcerative colitis with high phosphatase levels. Alpha 1 activity was most markedly increased in a patient with liver metastases $(17 \mathrm{~K}$.-A. units in alpha per $100 \mathrm{ml}$.) and was high in some cases of obstructive jaundice, biliary cirrhosis, hepatitis, haemochromatosis, and ulcerative colitis.

The pattern of increased beta as well as alpha 2 phosphatase activity found in bone disorders shows some overlap with the pattern of predominantly raised alpha 2 activity with some alpha 1 increase found in hepatobiliary disease, but in some cases the distinction is very striking. Increased alpha 1 phosphatase activity was more marked and more common in hepatobiliary disorders, but was also noted in bone disease. (The small number of cases of bone disease in this series prevents a firm conclusion on this point.)

The presence of alkaline phosphatase with different electrophoretic mobilities in the serum could be interpreted by supposing that several tissues, notably bone and liver, serve as a source of the enzyme in the blood, and that phosphatases derived from them have different mobilities.

The suggestion (Keiding, 1959) that beta globulin phosphatase has a special relationship to increased bone phosphatase activity, and that alpha 1 phosphatase has a connexion with liver phosphatase
(Rosenberg, 1959), is supported by the present study, though increased enzyne activity in these fractions is not specific for bone or hepatobiliary disorders respectively.

Rosenberg (1959) has postulated an alternative interpretation of the findings. He suggested that alkaline phosphatase in the course of its excretion by the liver might be altered in some way so that its electrophoretic mobility is changed, and some of this enzyme might then pass back into the plasma, thus accounting for the presence of several fractions. Both these interesting views on alkaline phosphatase metabolism remain speculative.

The simplicity of the technique used in this study brings it within the scope of most hospital laboratories. It is hoped that this will stimulate observations on larger series of cases.

This work was supported by a grant from the Medical Research Committee, St. Vincent's Hospital, Sydney. My thanks are due to Dr. R. D. Rothfield and Miss L. Silvester for much valuable advice, and to Miss J. McIlraith for technical assistance.

\section{REFERENCES}

Baker, R. W. R., and Pellegrino, C. (1954). Scand. J. clin. Lab. Invest., 6,94 .

Bessey, O. A., Lowry, O. H., and Brock, M. J. (1946). J. biol. Chem., $164,321$.

Keiding, N. R. (1959). Scand. J. clin. Lab. Invest., 11, 106.

Korner, N. H. (1962). J. clin. Path., 15, 200.

Kowlessar, O. D., Pert, J. H., Haeffner, L. J., and Sleisenger, M. H. (1959). Proc. Soc. exp. Biol. (N.Y.), 100, 191.

Rosenberg, I. N. (1959). J. clin. Invest., 38, 630. 